\title{
RICHARD II
}

BY ANTHONY STEEL

"It is written with a zest and an incisive vigour, at times almost breathless, which carries the reader along." PROF. F. M. POWICKE in The Spectator "Profoundly learned but engagingly written....Collates the recent work of various specialists and presents as a coherent whole a new portrait of Richard." John O'London's Weekly

I6s. net

\section{LORD}

LIVERPOOL

AND

LIBERAL-TORYISM 1820-1827

\section{BY W. R. BROCK}

" Mr Brock has captured a fitting moment for putting a fragment of our political story into its place in the larger picture. It is a scholarly study. He has given us an authoritative story of the workings of the personal forces which Liverpool contrived to operate in the spirit described as 'Liberal-Toryism.' It is a revealing story.'

HON. R. D. DENMAN, M.P., News Letter

$$
\text { 8s. 6d. net }
$$

